\title{
Characterization of antibiotic resistant and enzyme producing bacterial strains isolated from the Arabian Sea
}

\author{
Preeti N. Tallur ${ }^{1} \cdot$ Dayanand B. Sajjan $^{2} \cdot$ Sikandar I. Mulla $^{2} \cdot$ Manjunatha P. Talwar $^{2}$ • \\ A. Pragasam ${ }^{1} \cdot$ Vinayak M. Nayak $^{1} \cdot$ Harichandra Z. Ninnekar ${ }^{2} \cdot$ Shivanand S. Bhat $^{1}$
}

Received: 27 November 2014/ Accepted: 27 June 2015/Published online: 11 January 2016

(c) The Author(s) 2016. This article is published with open access at Springerlink.com

\begin{abstract}
Marine bacteria are known to produce many bioactive molecules and extracellular enzymes of commercial importance. We have investigated the bacterial diversity of the coastal area of Karwar, Karnataka State, India. Among these bacterial isolates, five bacterial strains were selected and identified by their morphological, biochemical characteristics and phylogenetic analysis based on 16S rRNA gene sequences. The identified bacterial isolates, Bacillus toyonensis PNTB1, Lysinibacillus sphaericus $\mathrm{PTB}$, Vibrio vulnificus $\mathrm{PMD}$, Shewanella MPTDBS, and Pseudomonas chlororaphis PNTB were characterized for their tolerance to salt and antibiotics. Vibrio vulnificus PMD showed maximum tolerance at higher concentration of salt than other bacteria. These bacterial strains were screened for the production of extracellular enzymes such as lipase, cellulase, pectinase, tannase, chitinase, and L-glutaminase. Vibrio vulnificus showed maximum production of L-glutaminase enzyme. Bacillus toyonensis PNTB1 shows lipase, CM-cellulase and chitinase activities. These isolated bacterial cultures were also utilized most of the aromatic compounds at $7 \mathrm{mM}$. These findings indicate the organisms present in this zone may have more potential applications in bioremediation, agricultural, industrial, and therapeutics.
\end{abstract}

Electronic supplementary material The online version of this article (doi:10.1007/s13205-015-0332-3) contains supplementary material, which is available to authorized users.

Preeti N. Tallur

preetiksh2002@yahoo.co.in

1 Government Arts and Science College, Karwar, Karnataka, India

2 Department of Biochemistry, Karnatak University, Dharwad, Karnataka, India
Keywords Extracellular enzymes $\cdot$ Lysinibacillus sphaericus . Vibrio vulnificus - Bacillus toyonensis . Antibiotics · Aromatic compounds

\section{Introduction}

Marine environment is a source for the isolation of a novel microorganism(s) with the potentiality to produce active secondary metabolites. Among marine organisms, bacteria are of particular interest since they play a vital role in the cycle of matter in water (Rheinheimer 1980). Marine bacteria are well known for their varied bioactive properties, which include the production of secondary metabolites, highly thermostable enzymes and bioactive compounds (Ashadevi et al. 2008). So, it is important to determine the types of bacteria present in the marine ecosystem, the role they play in the functioning of that ecosystem (Nazia and Nuzhat 2006). Hence, in the present study an attempt has been made to isolate and biochemically characterize some of the important marine bacteria from coastal area of Karwar (Karnataka State, India), with a view to identify the organisms and to study their salt tolerance, maximum tolerable concentration of antibiotics, utilization of various aromatic compounds as a growth substrate and also to evaluate their enzyme production potentials. There are reports on the study of marine bacterial diversity from different coastal area of sea (Chiaki et al. 1985; Bozal et al. 2002; Zamudio-Maya et al. 2008; Bal et al. 2009; Aureen et al. 2010; Aisha and Nuzhat 2011). There are very few reports on microorganisms which were isolated from coastal area of Karwar (Pankaj et al. 2011, 2013; Sanjay Kumar and Nagappa 2011; Shreedevi and Rathod 2011). However, there is not much information available on the bacterial cultures 
isolated from coastal area of Arabian Sea (Karwar, Karnataka State, India) having the ability of producing various extracellular enzymes with maximum tolerance of different antibiotics and salt concentrations and also utilization of various aromatic compounds. Karwar is the coastal city of Arabian Sea and Head Quarters of Uttar Kannada District and is in the West-coast of India, is situated $13^{1} 55^{11} \mathrm{~N}$ latitude and $7.40^{1} 5-75^{1} 05^{1} \mathrm{E}$ longitude. This place is gained a prominent place in the map of India because of the location of the recently commissioned Indian Naval Base called 'Sea Bird' and Kaiga Atomic Power Station in its vicinity. In the present study, we describe the cultural, morphological and biochemical characterization of pure bacterial cultures, isolated from marine sediments, west coastal area of Arabian Sea. Further, they were identified on the basis of 16S rRNA gene sequence analysis. In addition, we also present results of the bacterial cultures having the ability to various extracellular enzyme activities with their maximum tolerance towards various antibiotics and salt concentrations. These pure bacterial cultures were also utilizing various aromatic compounds as a growth substrate.

\section{Materials and methods}

\section{Chemicals}

Chlorobenzene, nitrobenzene, phenol, $m$-cresol, $p$-cresol, chitin, L-glutamine, nutrient agar, pectin, tetracycline, streptomycin, ampicillin, ciprofloxacin, penicillin, gentamicin, chloramphenicol, $p$-chloroaniline, $p$-nitrophenol, and penicillin were purchased from Merck, Himedia, SD Fine Chemicals Ltd., Sisco Research Laboratories Pvt. Ltd. (SRL) and Sigma-Aldrich, India. Nutrient media was procured from Himedia (India). All chemicals used are Analytical Reagent (AR) grade.

\section{Isolation and identification of pure bacterial strains}

Samples were taken for serial dilutions up to $10^{8} ; 100 \mu \mathrm{l}$ of samples of each dilution were inoculated on the nutrient agar plates for the isolation of bacteria by spread plate technique. The plates were incubated at $37{ }^{\circ} \mathrm{C}$ for $48 \mathrm{~h}$, and well separated bacterial colonies with different color were selected for further isolation and purification process. The process was repeated several times to get a pure individual bacterial culture. The pure bacterial cultures were maintained on the nutrient agar slant at $4{ }^{\circ} \mathrm{C}$, sub-culturing once in a month.

The cultural, morphological, and biochemical characteristics of the isolated bacterial strains were studied by adopting the methods described in the standard manuals
(Coon et al. 1957; Holding and Collee 1971; Seeley and Van Dan Demark 1972). Gram reaction and morphology of the bacterium were determined from both nutrient agar. The motility test was performed by hanging drop method, and Gram staining was done with ammonium oxalatecrystal violet (Seeley and Van Dan Demark 1972). Spores were observed by staining with malachite green. The pigmentation was observed on King A and King B media. Acid production from sugars and oxidative-fermentation was performed using the method of Hugh-Leifson (1953). Reduction of nitrate and nitrite were tested in liquid medium supplemented with either $0.1 \% \mathrm{KNO}_{3}$ or $\mathrm{KNO}_{2}$. Nitrate reduction to nitrite was detected by adding naphthylamine and sulphanilic acid reagents as described by Smibert and Krieg (1981). Starch hydrolysis was detected in agar medium supplemented with $1 \%$ soluble starch using iodine indicator. Growth at different temperatures (4-50 ${ }^{\circ} \mathrm{C}$ ) and tolerance to different $\mathrm{pH}$ (4-12) was determined.

\section{Identification of bacterial isolate by $16 \mathrm{~S}$ rRNA gene sequencing}

The bacterial 16S rRNA gene was amplified from the total genomic DNA using universal specific primers $63 \mathrm{~F}$ (5'CAGGCCTAACACATGCAAGTC $3^{\prime}$ ) and 1387R ( $5^{\prime}$ GGGCGGAGTGTACAAGGC $3^{\prime}$ ), which yielded a product of approximately 1300 base pairs. The polymerase chain reaction (PCR) conditions were 33 cycles of $95{ }^{\circ} \mathrm{C}$ denaturation for $1 \mathrm{~min}$, annealing at $55^{\circ} \mathrm{C}$ for $43 \mathrm{~s}$ and extension at $72{ }^{\circ} \mathrm{C}$ for $1 \mathrm{~min}$ and in addition one cycle of extension at $72{ }^{\circ} \mathrm{C}$ for $7 \mathrm{~min}$. The PCR product was purified by $\mathrm{PEG}-\mathrm{NaCl}$ precipitation (Sambrook et al. 1989). Briefly, the PCR product was mixed with 0.6 volumes of PEG-NaCl solution (20\% PEG 6000, $2.5 \mathrm{M} \mathrm{NaCl}$ ) and incubated for $10 \mathrm{~min}$ at $37^{\circ} \mathrm{C}$. The precipitate was collected by centrifugation at $12,000 \times g$ for $10 \mathrm{~min}$. The pellet was washed twice with $70 \%$ ethanol and dried under vacuum, which was resuspended in distilled water at a concentration of $>0.1 \mathrm{pmol} / \mathrm{ml}$. The purified product was directly sequenced using a Big Dye Terminator kit (Applied Biosystems, Foster City, USA). The sequencing reactions were run on AB1-PR1SM automated sequencer (ABI-373xl genetic analyzer). The nucleotide sequence analysis was done at the Blastn site at the NCBI server (http://www.ncbi.nlm.nih.gov/BLAST). The alignment of the sequences were done using CLUSTALW program VI.82 at the European Bioinformatics site (http://www.ebi. ac.uk/clustalw). The sequence was refined manually after cross checking with the raw data to remove ambiguities. The phylogenetic tree was constructed using the aligned sequences by the Neighbor-joining method using Kimura2-parameter distances in the MEGA beta 5.1 software 


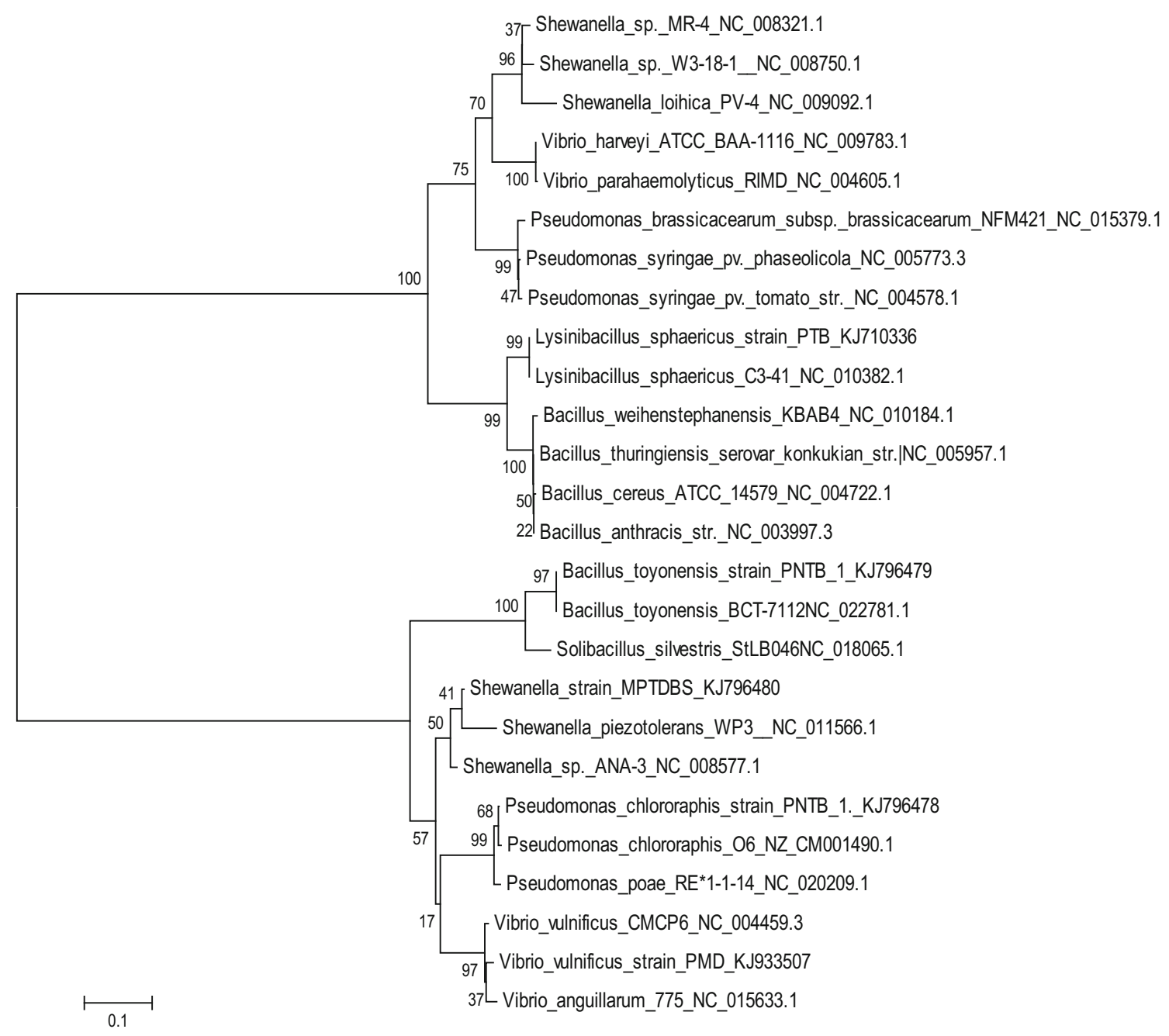

Fig. 1 Phylogenetic tree of pure bacterial isolates

(Tamura et al. 2011). Phylogenetic relationship was established by Bootstrap method with its bootstrap replication number 1000 and Kimura 2-parameter model as shown in Fig. 1.

\section{Sample preparation for atomic force microscopy (AFM)}

The pure bacterial culture suspension was centrifuged at $9500 \times g$ for $10 \mathrm{~min}$ at $4{ }^{\circ} \mathrm{C}$, to settle the bacterial pellet. The pellet was washed five times with nano pure water. The suspension was filtered with the help of syringe fitted with glass wool. The final purified pellet was resuspended in nano pure water. The bacterial suspension with optimum cell density was directly applied to the clean glass slide and allowed to dry under laminar flow cabinet for $4 \mathrm{~h}$. The airdried slides were directly analyzed under Nanosurf easyScan 2 AFM (Nanosurf AG, Liestal, Switzerland) system in dynamic force with air mode (Greif et al. 2010).

\section{Screening for extracellular enzymes}

The ability of the pure bacterial cultures to produce lipase enzyme was carried out by growing the cultures on tributyrin agar base plates and observing the zone of clearance due to hydrolysis of tributyrin (Sirisha et al. 2010). Cellulose degrading enzyme activity of the isolated bacteria were identified by culturing on Czapeak-Dox medium supplemented with $1 \%$ carboxymethyl cellulase (CMC) according to the method described by Glina and Khatiel (2011). The tannase was tested by growing the cultures on nutrient agar plates containing tannic acid (2\%) and determining the tannase activity according to the method described by Couri and Farias (1995). The YEP medium was used for isolation of pectinase producing bacteria supplemented with $2 \%$ agar (Janani et al. 2011). The chitin utilization was carried out by bacterial in colloidal chitin-agar medium according to the method described by Hackman (Hackman 1962). The L-glutaminase enzyme 
Table 1 Cultural, morphological and biochemical characteristics of the isolated pure bacteria

\begin{tabular}{|c|c|c|c|c|c|}
\hline Characteristics & $\begin{array}{l}\text { Bacillus toyonensis } \\
\text { PNTB1 }\end{array}$ & $\begin{array}{l}\text { Lysinibacillus } \\
\text { sphaericus } \text { PTB }\end{array}$ & Vibrio vulnificus PMD & $\begin{array}{l}\text { Shewanella strain } \\
\text { MPTDBS }\end{array}$ & $\begin{array}{l}\text { Pseudomonas } \\
\text { chlororaphis } \text { PNTB }\end{array}$ \\
\hline \multicolumn{6}{|c|}{ Cultural and morphological characteristics } \\
\hline $\begin{array}{l}\text { Colony } \\
\text { morphology }\end{array}$ & $\begin{array}{l}\text { Irregular, curled, } \\
\text { umbonate, rough, } \\
\text { turbid white, opaque }\end{array}$ & $\begin{array}{l}\text { Regular, circular } \\
\text { smooth, raised } \\
\text { transparent, white }\end{array}$ & $\begin{array}{l}\text { Regular, smooth, circular, } \\
\text { concave transparent, } \\
\text { pale yellow }\end{array}$ & $\begin{array}{l}\text { Regular, circular, } \\
\text { transparent } \\
\text { glistening, smooth, } \\
\text { yellow }\end{array}$ & $\begin{array}{l}\text { Regular, entire, } \\
\text { opaque, smooth, } \\
\text { raised, pale yellow }\end{array}$ \\
\hline $\begin{array}{l}\text { Vegetative } \\
\text { cells }\end{array}$ & Rod & Rod & Rod & Rod & Rod \\
\hline Motility & + & - & + & + & + \\
\hline Gram reaction & + & + & - & - & - \\
\hline Endospores & + & + & - & - & - \\
\hline $\begin{array}{l}\text { Pigment } \\
\text { formation }\end{array}$ & - & - & - & - & $\begin{array}{l}\text { Fluorescent diffusible } \\
\text { pigment }\end{array}$ \\
\hline $\begin{array}{l}\text { Temperature } \\
\text { (optimum) }\end{array}$ & $10-45^{\circ} \mathrm{C}\left(37^{\circ} \mathrm{C}\right)$ & $20-40^{\circ} \mathrm{C}\left(30^{\circ} \mathrm{C}\right)$ & $20-45^{\circ} \mathrm{C}\left(30^{\circ} \mathrm{C}\right)$ & $15-40{ }^{\circ} \mathrm{C}\left(35^{\circ} \mathrm{C}\right)$ & $20-40{ }^{\circ} \mathrm{C}\left(30^{\circ} \mathrm{C}\right)$ \\
\hline $\mathrm{pH}$ (optimum) & $5.5-10(7.1)$ & $6-9(7.2)$ & $6-9.5(7.0)$ & $6.5-9.5(7.2)$ & $6-9(7.0)$ \\
\hline \multicolumn{6}{|c|}{ Biochemical characteristics } \\
\hline Catalase & + & + & + & + & + \\
\hline Oxidase & + & + & + & + & + \\
\hline Urease & - & + & + & + & \pm \\
\hline $\begin{array}{l}\text { Lysine } \\
\text { decarboxylase }\end{array}$ & + & + & + & + & - \\
\hline $\begin{array}{l}\text { Agrinine } \\
\text { dihydrolase }\end{array}$ & + & - & + & - & - \\
\hline $\begin{array}{l}\text { Starch } \\
\text { hydrolysis }\end{array}$ & + & + & + & - & \pm \\
\hline $\begin{array}{l}\text { Gelatin } \\
\text { hydrolase }\end{array}$ & + & + & - & + & - \\
\hline $\begin{array}{l}\mathrm{H}_{2} \mathrm{~S} \\
\text { production }\end{array}$ & - & - & - & - & - \\
\hline $\begin{array}{l}\text { Casein } \\
\text { hydrolysis }\end{array}$ & + & - & - & - & - \\
\hline $\begin{array}{l}\text { Indole } \\
\text { production }\end{array}$ & - & - & - & - & - \\
\hline $\begin{array}{l}\text { Ornithine } \\
\text { decarboxylase }\end{array}$ & - & - & + & + & + \\
\hline $\begin{array}{l}\text { Nitrate } \\
\text { Reduction }\end{array}$ & + & + & + & + & + \\
\hline ONPG & - & - & + & - & - \\
\hline $\begin{array}{l}\text { Citrate } \\
\text { utilization }\end{array}$ & + & - & + & + & - \\
\hline Methyl red test & - & - & - & - & - \\
\hline $\begin{array}{l}\text { Voges } \\
\text { Proskauer test }\end{array}$ & + & \pm & - & + & - \\
\hline \multicolumn{6}{|c|}{ Oxidation/fermentation $(\mathrm{O} / \mathrm{F})$} \\
\hline Mannitol & - & - & $\mathrm{O}$ and $\mathrm{F}$ & - & - \\
\hline Glucose & $\mathrm{O}$ and $\mathrm{F}$ & $\mathrm{O}$ and $\mathrm{F}$ & $\mathrm{O}$ and $\mathrm{F}$ & - & $\mathrm{O}$ and $\mathrm{F}$ \\
\hline Lactose & - & - & $\mathrm{O}$ and $\mathrm{F}$ & - & - \\
\hline \multicolumn{6}{|c|}{ Acid and gas production from carbohydrates } \\
\hline Mannitol & $-1-$ & $-1-$ & \pm & $-1-$ & $-1-$ \\
\hline Glucose & \pm & $+/+$ & \pm & $-1-$ & \pm \\
\hline Sucrose & \pm & $\pm /-$ & \pm & $-1-$ & \pm \\
\hline
\end{tabular}


Table 1 continued

\begin{tabular}{llllll}
\hline Characteristics & $\begin{array}{l}\text { Bacillus toyonensis } \\
\text { PNTB1 }\end{array}$ & $\begin{array}{l}\text { Lysinibacillus } \\
\text { sphaericus } \text { PTB }\end{array}$ & Vibrio vulnificus PMD & $\begin{array}{l}\text { Shewanella strain } \\
\text { MPTDBS }\end{array}$ & $\begin{array}{l}\text { Pseudomonas } \\
\text { chlororaphis } \text { PNTB }\end{array}$ \\
\hline Lactose & - I- & $\pm /-$ & \pm & $-/-$ & $-/-$ \\
Fructose & \pm & $-I-$ & \pm & $-/-$ & \pm \\
Galactose & \pm & $-I-$ & \pm & \pm & $-/-$ \\
Maltose & \pm & $-/-$ & \pm & $-/-$ & \pm \\
Xylose & $-/-$ & $-/-$ & \pm & $-/-$ & $-/-$ \\
Arabinose & $-/-$ & \pm & $-/-$ & $-/-$ \\
\hline
\end{tabular}

Cultural and morphological characteristics: + present, - absent; Biochemical characteristics: \pm present or absent, - no O/F, \pm acid production from carbohydrate/no gas production from carbohydrate, $-/-$ no acid/no gas production, $+/+$ acid/gas production, $\pm /-$ acid or no acid production from carbohydrate/no gas production from carbohydrate

producing bacteria were isolated according to the method described by Kiruthika and Saraswathy (2013). The total protein concentration was determined by standard Bradford assay using commercial reagent (Bio-Rad, Hercules, USA) according to the instruction manual (Bradford 1976).

\section{Maximum tolerable concentration for antibiotics and sodium chloride}

Maximum tolerable concentrations for antibiotics of the isolated bacteria to different antibiotics were tested on a nutrient agar plate (Well-diffusion method) (Yilmaz et al. 2006). The antibiotics tested for maximum tolerable concentration were tetracycline (TET), norfloxacin (NOR), streptomycin (STP), ampicillin (Amp), ciprofloxacin (CIP), gentamicin (GEN), chloramphenciol (CHL), and penicillin (PEN). Maximum tolerable concentrations of sodium chloride was carried out by the growth of bacteria in nutrient broth containing 5-30\% salt contractions.

\section{Utilization of various aromatic compounds by pure bacterial cultures}

The ability of the individual bacterial cultures to utilize aromatic compounds as a sole source of carbon and energy was determined by measurement of growth in mineral salts medium (MM 1) containing $7 \mathrm{mM}$ of the compound (Hoskeri et al. 2011; Mulla et al. 2012). The growth was measured turbidometrically at $600 \mathrm{~nm}$.

\section{Results and discussion}

In the present study five commercially exploitable strains of pure bacterial cultures have been selected for extracellular enzyme activities, utilization of various aromatic compounds as a growth substrate, maximum tolerance towards various antibiotics and salt concentrations studies.
All the isolated pure bacterial cultures were gram-positive and gram-negative, rod-shaped and aerobic. The cultural, morphological, and biochemical characteristics of the isolated pure bacterial cultures are given in Table 1 . According to Bergey's Manual of Determinative Bacteriology (Holt et al. 1994) and by phylogenetic analysis based on 16S rRNA gene sequences, the isolates were identified as Bacillus toyonensis strain PNTB1, Lysinibacillus sphaericus strain $\mathrm{PTB}$, Vibrio vulnificus strain PMD, Shewanella strain MPTDBS, and Pseudomonas chlororaphis PNTB. Their sequences were deposited in Genbank under accession number KJ796479, KJ710336, KJ933507, KJ796480, and KJ796478, respectively. The individual pure culture 16S rRNA gene sequence analysis was done at RDP II and NCBI, where relevant sequences from these databases were downloaded for further analysis (Hoskeri et al. 2011). The phylogenetic relationship of isolated individual pure bacterial cultures with other bacterial cultures is shown in Fig. 1. The individual pure bacterial culture is closely aligned with their respective genus between 95 and $100 \%$ (Fig. 1). Also, these pure cultures were analyzed by AFM. AFM is a powerful tool for the analysis of topographical features of bacteria with little or no modification of the sample. It is versatile, robust, fast and economical compared other structural analysis techniques. Vibrio vulnificus PMD was found to be rod shaped with an average length of $442.14 \mathrm{~nm}$ and height of $23.178 \mathrm{~nm}$ (Fig. 2a). Shewanella strain MPTDBS was found to be rod shaped with an average length of $1.497 \mu \mathrm{m}$ and height of $130.54 \mathrm{~nm}$ (Fig. 2b). Lysinibacillus sphaericus strain PTB has two morphological forms, vegetative rod bacterium, and spherical spores. AFM analysis of spores $L$. sphaericus have typical spherical shapes with an average diameter of $518.5 \mathrm{~nm}$ and height of $61.342 \mathrm{~nm}$ (Fig. 2c). Pseudomonas chlororaphis PNTB1 was found to be rod shaped with an average length of $2.498 \mu \mathrm{m}$ and height of $284.084 \mathrm{~nm}$ (Fig. 2d). Bacillus toyonensis strain PNTB1 was found to be rod shaped with an average length 

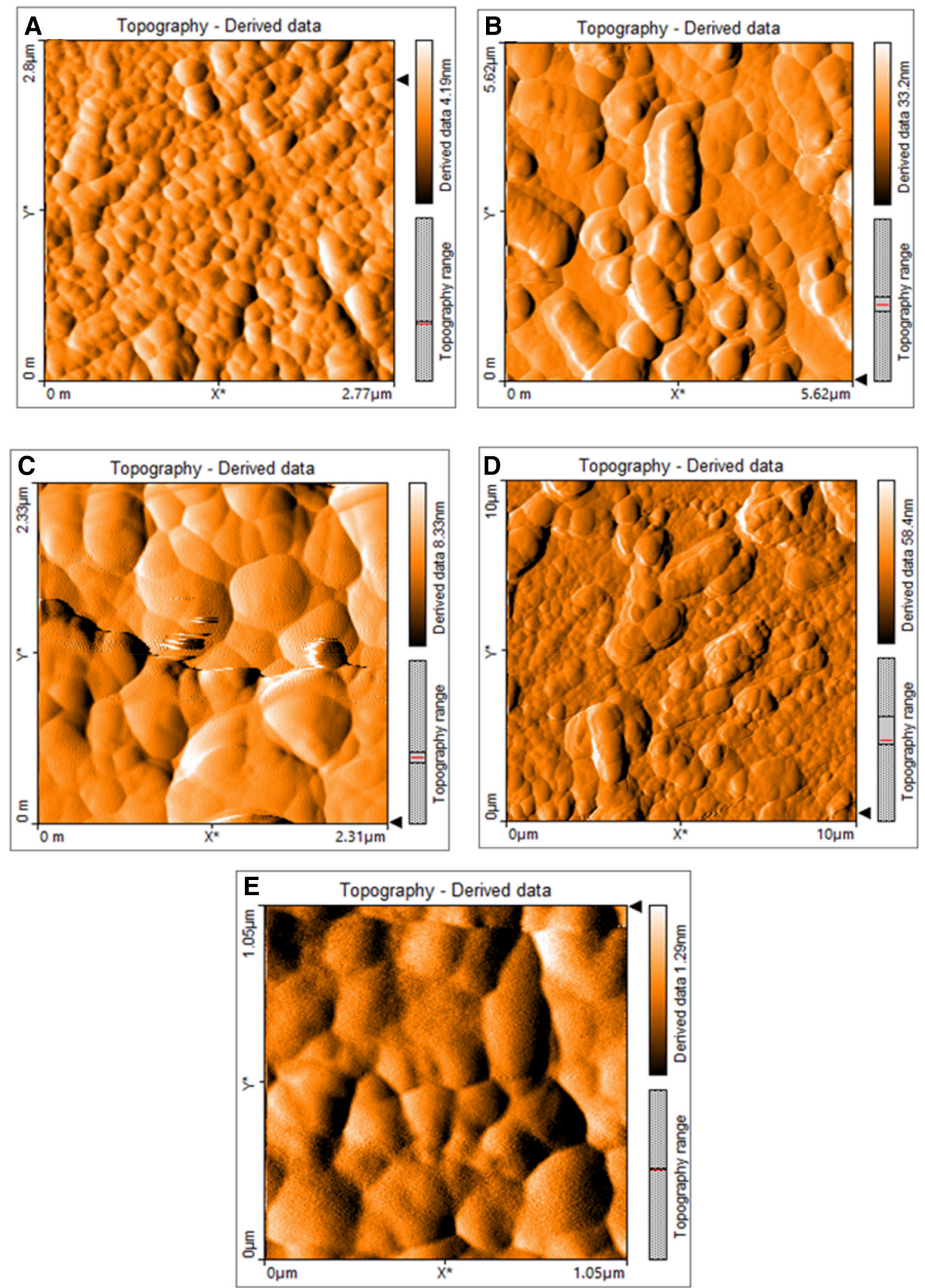

Fig. 2 AFM pictures of a Vibrio vulnificus PMD, b Shewanella strain MPTDBS, c Lysinibacillus sphaericus PTB, $\mathbf{d}$ Pseudomonas chlororaphis PNTB, e Bacillus toyonensis PNTB1 
Fig. 3 Maximum tolerable concentration for antibiotics of the isolated bacteria

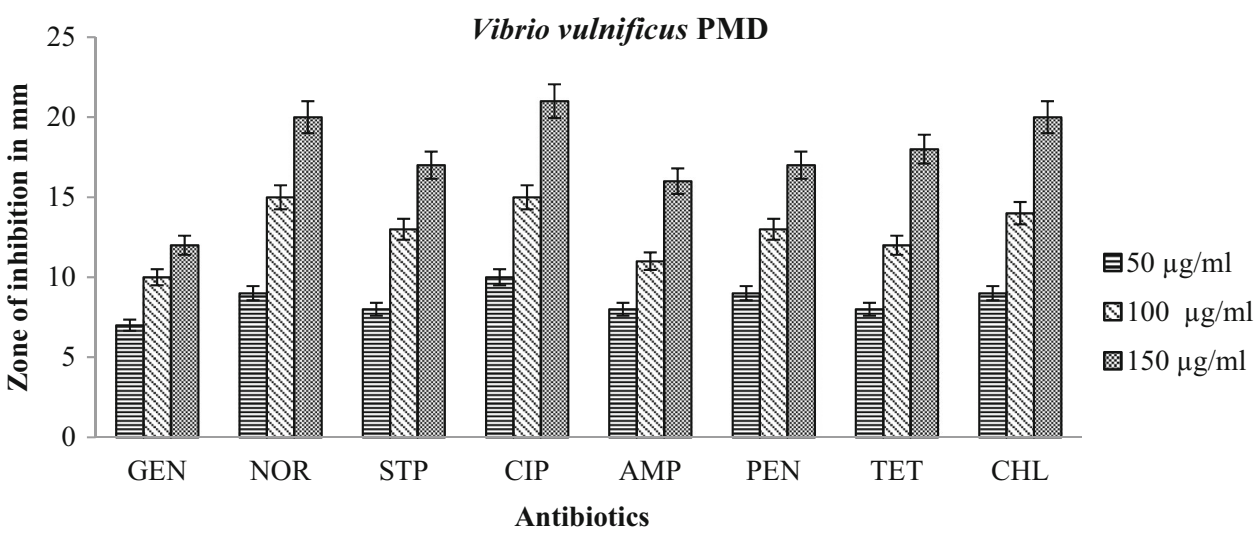

Shewanella strain MPTDBS
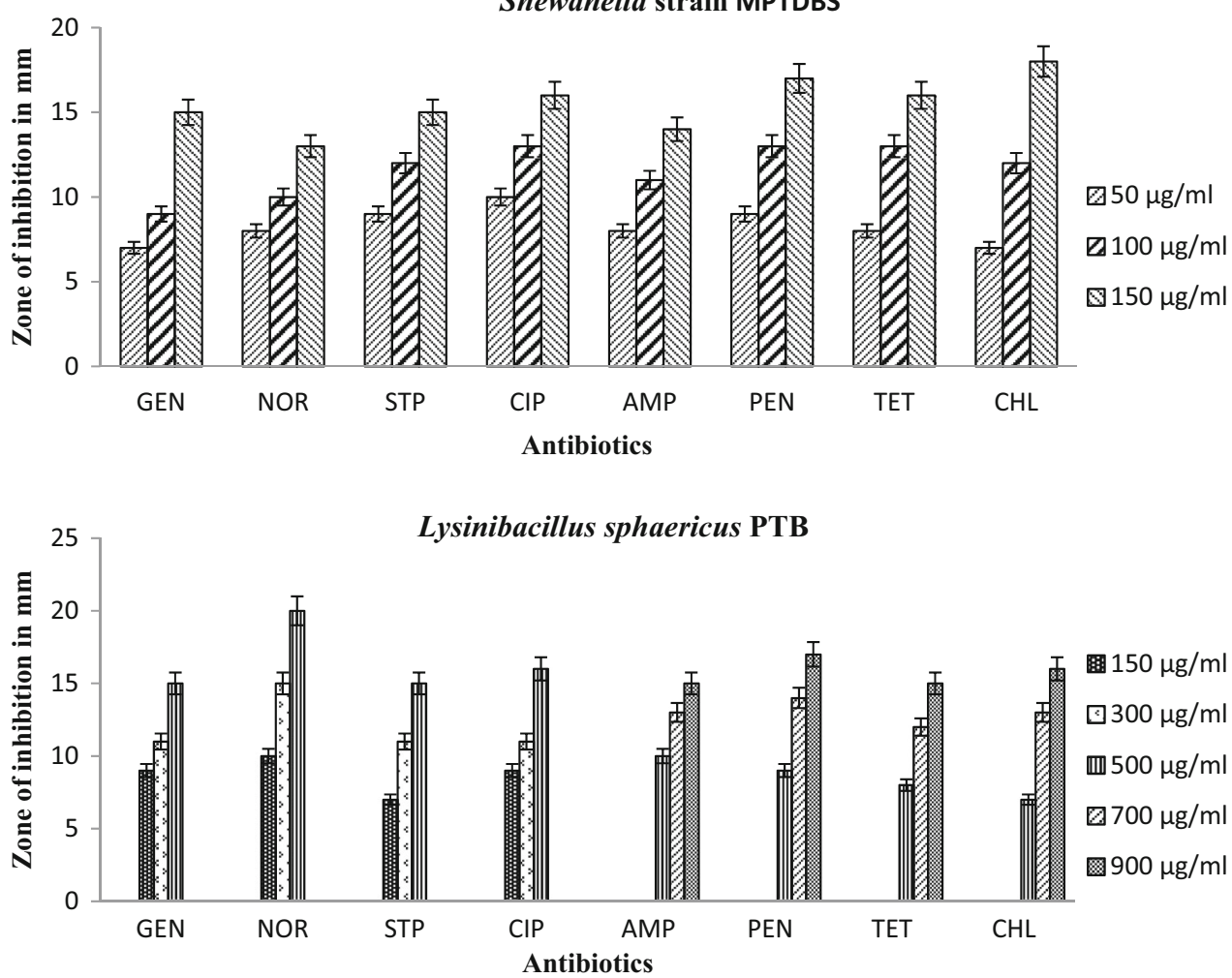

of $453.436 \mathrm{~nm}$ and height of $9.235 \mathrm{~nm}$ (Fig. 2e). Although AFM suffers from minor flaws in the length measurement, due to its probe tip lateral surface interaction with the sample (Kuznetsov and McPherson 2011). Hence, the isolated pure bacterial cultures are the novel strains of their corresponding bacterial genus.

Lysinibacillus sphaericus is a spore-forming bacterium used in the biological control of mosquitoes and in bioremediation (Lozano and Jenny 2013; Silva-Filha et al. 2014; Wirth et al. 2014). Lysinibacillus sphaericus tolerate and reduces heavy metals and also used in the preparation of nanoparticles (Yujun et al. 2015). Similarly, Shewanella strain is also a novel sp., having ability to reduce mercury, iron, uranium, and plutonium metabolically (Ling and
Jeremy 2014) and able to synthesize As-S nanotubes via the combined reduction of arsenate and thiosulfate. The biogenic formation of one-dimensional As-S nanotubes greatly contribute to new green biosynthetic methods for the production of inorganic materials at nanoscales, which used in nano and optoelectronic devices (Wiatrowski et al. 2006; Jiang et al. 2009). Pseudomonas chlororaphis use as soil inoculants for plants as a bio-controlling agent against Fusarium oxysporum fungus, a causative agent of tomato foot and root rot (Chin et al. 2000). Bacillus toyonensis is a active ingredient of the preparation of commercial animal nutrient Toyocerin which is used for feeding house hold animals such as swine, poultry, cattle, rabbits and aquaculture (Jiménez et al. 2013). 
Fig. 3 continued
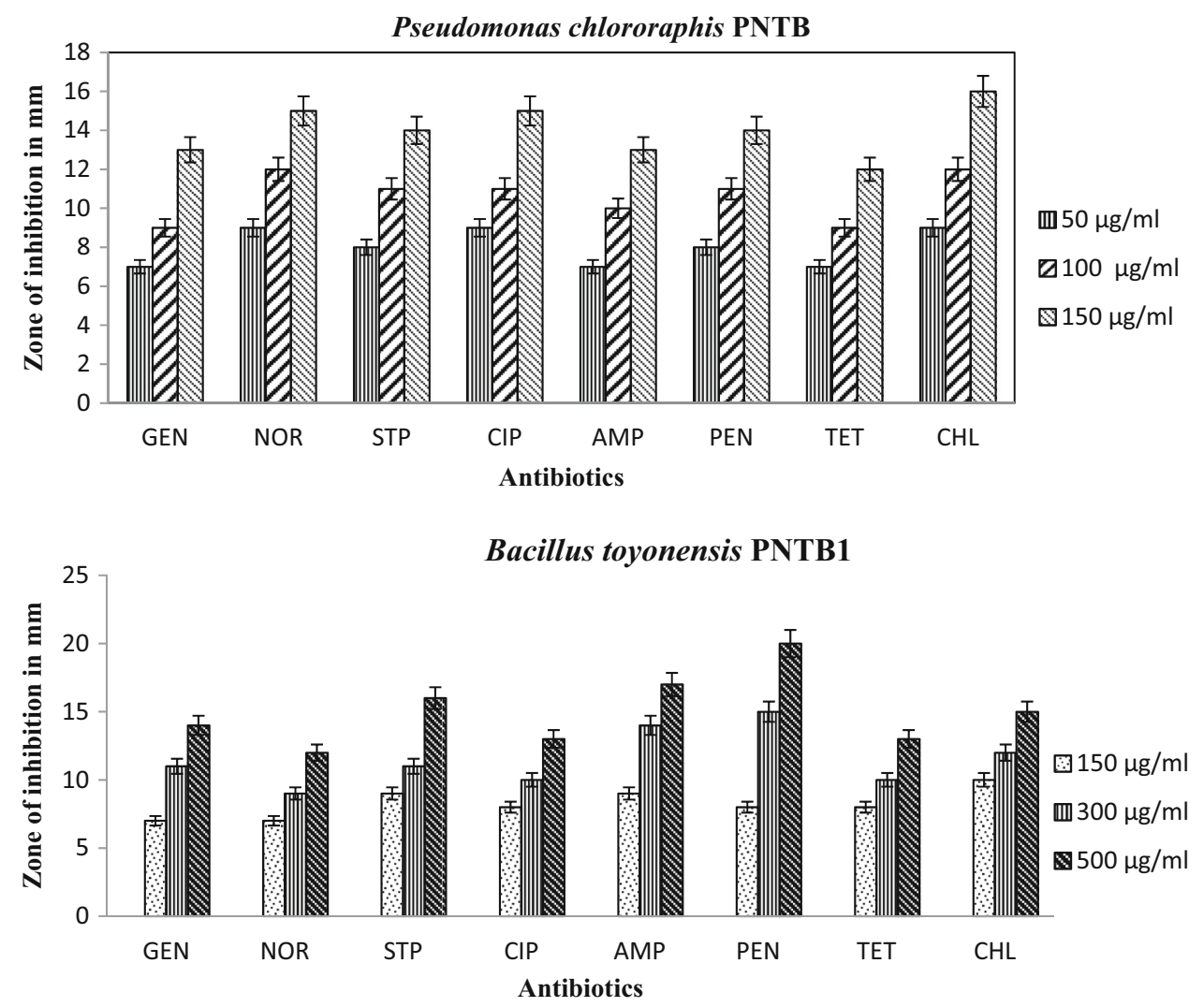

Table 2 Maximum tolerable concentration of sodium chloride

\begin{tabular}{llllll}
\hline $\begin{array}{l}\text { Salt concentration } \\
(\%)\end{array}$ & $\begin{array}{l}\text { Bacillus toyonensis } \\
\text { PNTB1 }\end{array}$ & $\begin{array}{l}\text { Lysinibacillussphaericus } \\
\text { PTB }\end{array}$ & $\begin{array}{l}\text { Vibrio vulnificus } \\
\text { PMD }\end{array}$ & $\begin{array}{l}\text { Shewanella strain } \\
\text { MPTDBS }\end{array}$ & $\begin{array}{l}\text { Pseudomonas chlororaphis } \\
\text { PNTB }\end{array}$ \\
\hline 5 & + & + & + & + & + \\
10 & + & + & + & + & + \\
12 & + & + & + & + & + \\
15 & + & - & + & - & + \\
20 & - & - & + & - & - \\
25 & - & - & + & - & - \\
30 & - & - & - & & \\
\hline
\end{tabular}

+ growth, - no growth

The isolates Bacillus toyonensis strain PNTB1, Lysinibacillus sphaericus strain PTB shows resistant to lower concentration of antibiotics, Vibrio vulnificus PMD, Shewanella strain MPTDBS and Pseudomonas chlororaphis PNTB were sensitive to lower concentration of antibiotics shown in Fig. 3. The Vibrio vulnificus PMD tolerate high concentration of salt compare to other isolates shown in Table 2. A total of 54 isolates were taken for the study of extracellular enzyme activities, out of them Bacillus toyonensis strain PNTB1, Lysinibacillus sphaericus strain PTB, Vibrio vulnificus PMD, Shewanella strain MPTDBS, and Pseudomonas chlororaphis PNTB were found to be potential source of commercially important enzymes and the activities were found to be maximum in these stains compared to other microorganisms. The extracellular enzyme activities of the isolated bacteria are shown in Table 3. Vibrio vulnificus shows glutaminase activity up to $24 \mathrm{U} / \mathrm{ml}$ whereas Streptomyces sp. showed upto $18.0 \mathrm{U} / \mathrm{ml}$ (Krishnakumar et al. 2011). Lysinibacillus sphaericus PTB, Bacillus toyonensis PNTB1, Shewanella strain MPTDBS, and Pseudomonas chlororaphsis PNTB showed lipase activity up to $50.58,49.28,48.24$, and $48.1 \mathrm{U} / \mathrm{ml}$, respectively, whereas Staphylococcus sp., and Bacillus sp. showed lipase activity up to 48 and $26.37 \mathrm{U} / \mathrm{ml}$, respectively (Sebdani et al. 2011; Sirisha et al. 2010). Bacillus toyonensis PNTB1 showed cellulase activity upto 0.47 
$\mathrm{U} / \mathrm{ml}$ whereas Cellulomonas sp. showed upto $0.450 \mathrm{U} / \mathrm{ml}$ (Muhammad et al. 2012). Bacillus toyonensis PNTB1 showed chitinase activity upto $56.12 \mathrm{U} / \mathrm{ml}$ whereas Aeromonas hydrophila and Aeromonas punctata showed up to 43.08 and $53.22 \mathrm{U} / \mathrm{ml}$, respectively (Saima and Roohi 2013). Bacillus toyonensis strain PNTB1 shows lipase, cellulase and chitinase activities whereas other isolated pure cultures were not shown cellulase and chitinase activities. Shewanella strain MPTDBS and Pseudomonas chlororaphis PNTB showed lipase activity. Lysinibacillus sphaericus $\mathrm{PTB}$, shows maximum lipase activity compare to other isolates. Vibrio vulnificus PMD shows L-glutaminase enzyme activity. L-Glutaminase is a very important enzyme due to its role as a flavor enhancer and

Table 3 Extracellular enzyme activities of pure bacterial isolates

\begin{tabular}{lc}
\hline Bacteria & Enzyme activity (units/ml) \\
\hline Lipase & \\
Bacillus toyonensis & $49.28 \pm 0.01^{\mathrm{a}}$ \\
Lysinibacillus sphaericus & $50.58 \pm 0.02^{\mathrm{a}}$ \\
Shewanella strain & $48.24 \pm 0.04^{\mathrm{a}}$ \\
Pseudomonas chlororaphis & $48.1 \pm 0.02^{\mathrm{a}}$ \\
Cellulase & \\
Bacillus toyonensis & $0.47 \pm 0.01^{\mathrm{a}}$ \\
Chitinase & \\
Bacillus toyonensis & $56.12 \pm 0.03^{\mathrm{a}}$ \\
L-glutaminase & $24 \pm 0.01^{\mathrm{a}}$ \\
Vibrio vulnificus & \\
\hline
\end{tabular}

${ }^{\text {a }}$ Enzyme activities are the mean \pm SE of assays from triplicate cell free extracts antileukemic agent (Krishnakumar et al. 2011; Yulianti et al. 2012; Kiruthika and Saraswathy 2013). The isolates did not show tannase and pectinase activity. Also, the individual pure cultures were utilized various aromatic compounds as their growth substrates (Table 4). Bacillus toyonensis strain PNTB1 has showed good growth on MM 1 containing $p$-chloroaniline, chlorobenzene, and $p$-cresol. However, the bacterium does not utilize $m$-cresol as a growth substrate. Similarly, Lysinibacillus sphaericus strain PTB showed growth on $p$-chloroaniline, phenol, deltamethrin, but not on $p$-cresol, $m$-cresol and chlorobenzene. Vibrio vulnificus PMD showed growth on $p$-chlorophenol but not on $p$-chloroaniline, $p$-nitrophenol an $m$-cresol. Shewanella strain MPTDBS showed good growth on nitrobenzene and phenol but not on $m$-cresol and p-chlorophenol. Pseudomonas chlororaphis PNTB1 showed growth on $p$-chloroaniline, chlorobenzene and deltamethrin but not on $m$-cresol and $p$-chlorophenol. Further experiments on genomics, proteomics and degradation of specific substrates (aromatic compounds) by individual organisms having good growth are under progress. These results are encouraging as isolated bacterial cultures have novel applications.

Isolation of bacteria from the marine environment may provide ample scope to assess their therapeutic, pest controlling, industrial, and bioremediation potential. This work represents an emerging view of the bacterial diversity of West coastal area of Arabian Sea, Karwar (Karnataka State, India). Since, there was not much information available on bacterial diversity from Karwar coast. Bacteria isolated in the present study indicate a promising source of microbial genetic resources to be biotechnologically explored.

Table 4 Utilization of various aromatic compounds by pure bacterial isolates

\begin{tabular}{|c|c|c|c|c|c|}
\hline \multirow[t]{2}{*}{ Substrate } & \multicolumn{5}{|l|}{ Growth } \\
\hline & $\begin{array}{l}\text { B. toyonensis strain } \\
\text { PNTB1 }\end{array}$ & $\begin{array}{l}\text { L. sphaericus strain } \\
\text { PTB }\end{array}$ & $\begin{array}{l}\text { V. vulnificus strain } \\
\text { PMD }\end{array}$ & $\begin{array}{l}\text { Shewanella strain } \\
\text { MPTDBS }\end{array}$ & $\begin{array}{l}\text { P. chlororaphis strain } \\
\text { PNTB1 }\end{array}$ \\
\hline$p$-Chloroaniline & ++ & ++ & - & + & ++ \\
\hline Nitrobenzene & - & + & + & ++ & + \\
\hline Chlorobenzene & ++ & - & + & + & ++ \\
\hline$p$-Nitrophenol & + & + & - & + & + \\
\hline Phenol & + & ++ & + & ++ & + \\
\hline$p$-Cresol & ++ & - & + & + & + \\
\hline$m$-Cresol & - & - & - & - & - \\
\hline p-Chlorophenol & + & + & ++ & - & - \\
\hline Deltamethrin & + & ++ & + & + & ++ \\
\hline Cypermethrin & + & + & + & + & + \\
\hline
\end{tabular}

++ good growth, + moderate growth, - no growth 
Acknowledgments The corresponding author is thankful to the University Grant Commission, India for financial support to carry out this work, MRP(S)-1107/11-12/KAKA088/UGC-SWRO.

\section{Compliance with ethical standards}

Conflict of interest The authors declare that they have no competing interests.

Open Access This article is distributed under the terms of the Creative Commons Attribution 4.0 International License (http:// creativecommons.org/licenses/by/4.0/), which permits unrestricted use, distribution, and reproduction in any medium, provided you give appropriate credit to the original author(s) and the source, provide a link to the Creative Commons license, and indicate if changes were made.

\section{References}

Aisha N, Nuzhat A (2011) Isolation and characterization of indigenous luminescent marine bacteria from Karachi coast. Acad Res Int 2(2):74-83

Ashadevi NK, Balakrishnan K, Gopal R, Padmavathy S (2008) Bacillus clausii MB9 from the east coast regions of India: isolation, biochemical characterization and antimicrobial potentials. Curr Sci 95(5):627-636

Aureen G, Ramesh R, Saroj B (2010) Bacteria from sand dunes of Goa promoting growth in egg plant. World J Agric Sci 6(5):555-564

Bal S, Mishra RR, Rath B, Sahu HK, Thatoi HN (2009) Isolation and extracellular enzyme activity of predominant marine Bacillus sp. isolated from sea water of Orissa coast. Malays J Microbiol 5(2):87-93

Bozal N, Montes MJ, Tudela E, Jimenez F, Guinea J (2002) Shewanella frigidimarina and Shewanella livingstonensis sp. nov. isolated from Antarctic coastal areas. Int J Syst Evol Microbiol 52:195-205

Bradford MM (1976) Rapid and sensitive method for the quantitation of microgram quantities of protein utilizing the principle of protein-dye binding. Anal Biochem 72:248-254

Chiaki I, Usio S, Nobuo T (1985) Isolation and characterization of marine bacteria producing alkaline protease inhibitor. Bull Jpn Soc Sci Fish 52(5):799-803

Chin AWTF, Bloemberg GV, Mulders IH, Dekkers LC, Lugtenberg BJ (2000) Root colonization by phenazine-1-carboxamide-producing bacterium Pseudomonas chlororaphis PCL1391 is essential for biocontrol of tomato foot and root rot. Mol Plant Microbe Interact MPMI 13(12):1340-1345

Coon HJ, Jenison MW, Weeks OB (1957) Manual of microbiological methods. Mc Graw Hill Book Co., Inc., New York

Couri S, Farias AX (1995) Genetic manipulation of Aspergillus niger for increased synthesis of pectinolytic enzymes. Rev Microbiol 26(4):314-317

Glina VV, Khatiel KM (2011) Cellulase enzyme activity of Aspergillus fumigates from Mangrove soil on lignocellulosic substrate. Recent Res Sci Technol 3(1):132-134

Greif D, Wesner D, Regtmeier J, Anselmetti D (2010) High resolution imaging of surface patterns of single bacterial cells. Ultramicroscopy 110(10):1290-1296

Hackman RH (1962) Studies on chitin V. The action of mineral acids on chitin. Aust J Biol Sci 15:526-537

Holding AJ, Collee JG (1971) Routine biochemical tests. Academic Press, London and New York
Holt JG, Krieg NR, Sneath PHA, Staley JT, Williams ST (1994) Bergey's manual of determinative bacteriology. Williams and Wilkins, Baltimore

Hoskeri RS, Mulla SI, Shouche YS, Ninnekar HZ (2011) Biodegradation of 4-chlorobenzoic acid by Pseudomonas aeruginosa PA01 NC. Biodegradation 22(3):509-516

Hugh R, Leifson E (1953) The taxonomic significance of fermentative versus oxidative metabolism of carbohydrates by various gramnegative bacteria. J Bacteriol 66(1):24-26

Janani L, Gaurav Kumar KV, Rao B (2011) Screening of pectinase producing microorganisms from agricultural waste dump soil. Asian J Biochem Pharm Res 1(2):329-337

Jiang S, Lee JH, Kim MG, Myung NV, Fredrickson JK, Sadowsky MJ, Hur HG (2009) Biogenic formation of As-S nanotubes by diverse Shewanella strains. Appl Environ Microbiol 75(21):6896-6899

Jiménez G, Blanch AR, Tamames J, Rosselló-Mora R (2013) Complete genome sequence of Bacillus toyonensis BCT$7112^{\mathrm{T}}$, the active ingredient of the feed additive preparation toyocerin. Genome Announc 1(6):e01080-13

Kiruthika J, Saraswathy N (2013) Production of L-glutaminase and its optimization from a novel marine isolate Vibrio azureus JK-79. Afr J Biotechnol 12(50):6944-6953

Krishnakumar S, Alexis Rajan R, Ravikumar S (2011) Extracellular production of L-glutaminase by marine alkalophilic Streptomyces sp. SBV1 isolated from Cape Comorin coast. Indian J Geo-mar Sci 40(5):717-721

Kuznetsov YG, McPherson A (2011) Atomic force microscopy in imaging of viruses and virus-infected cells. Microbiol Mol Biol Rev MMBR 75(2):268-285

Ling S, Jeremy BF (2014) Uranium reduction by Shewanella oneidensis MR-1 as a function of $\mathrm{NaHCO}_{3}$ control of reduction kinects. Environ Sci Technol 48(7):3768-3775

Lozano LC, Jenny D (2013) Metal tolerance and larvicidal activity of Lysinibacillus sphaericus. World J Microbiol Biotechnol 29:1383-1389

Muhammad I, Asma S, Quratulain S, Muhammad N (2012) Isolation and screening of cellulolytic bacteria from soil and optimization of cellulase production and activity. Turk $\mathrm{J}$ Biochem 37(3):287-293

Mulla SI, Talwar MP, Hoskeri RS, Ninnekar HZ (2012) Enhanced degradation of 3-nitrobenzoate by immobilized cells of Bacillus flexus strain XJU-4. Biotechnol Bioproc E 17(6):1294-1299

Nazia J, Nuzhat A (2006) Characterization of bacterial flora from coastal areas of Pakistan. J Basic Appl Sci 2(2):89-93

Pankaj V, Prashant Kumar P, Arvind Kumar G, Ho Jun K, Keun SK, Chi NS, Milind SP, Yogesh SS (2011) Shewanella indica sp. nov., isolated from sediment of the Arabian Sea. Int J Syst Evolut Microbiol 61:2058-2064

Pankaj V, Chi NS, Prashant Kumar P, Ramesh RB, Cathrin S, Manfred R, Yogesh SS (2013) Bhargavaea indica sp. nov., a member of the phylum Firmicutes isolated from Arabian Sea sediments. J Microbiol 51(1):36-42

Rheinheimer G (1980) Aquatic microbiology. New York, John Wiley

Saima MD, Roohi IZ Ahmad (2013) Isolation of novel chitinolytic bacteria and production optimization of extracellular chitinase. J Genetic Eng Biotechnol 1:39-46

Sanjay Kumar S, Nagappa R (2011) Denaturing gradient gel electrophoresis profiling of bacteria communities composition in Arabian Sea. J Environ Biol 32:339-346

Sambrook J, Fritsch EF, Maniatis T (1989) Molecular Cloning: A laboratory manual, vol 3, 2nd edn. Cold Springs Harbor Laboratory, Cold Springs Harbor, New York

Sebdani RM, Ardakani MR, Ghezelbash GR, Sadrinasab M (2011) Phylogenic characterisation of lipase producing Bacillus strains 
isolated from Persian Gulf sediments. Aust J Basic Appl Sci 5(4):121-126

Seeley HW, Van Dan Demark PJ (1972) Microbes in action-a laboratory manual of Microbiology. Freeman, San Francisco, p 361

Shreedevi SK, Rathod JL (2011) Isolation and enumeration of flora in false trevally, Lactarius lactarius of Karwar, central west coast of India. Indian J Geo-Mar Sci 40(4):583-586

Silva-Filha MHNL, Berry C, Regis L (2014) Chapter three-Lysinibacillus sphaericus: toxins and mode of action, applications for mosquito control and resistance management. Elsevier, Amsterdam

Sirisha E, Rajasekar N, Lakshmi Narasu M (2010) Isolation and optimization of lipase producing bacteria from oil contaminated soils. Adv Biol Res 4(5):249-252

Smibert RM, Krieg NR (1981) Manual of methods for general bacteriology. American Society for Microbiology, Washington

Tamura K, Peterson D, Peterson N, Stecher G, Nei M, Kumar S (2011) MEGA5: molecular evolutionary genetics analysis using maximum likelihood, evolutionary distance, and maximum parsimony methods. Mol Biol Evol 28(10):2731-2739

Wiatrowski HA, Ward PM, Barkay T (2006) Novel reduction of mercury (II) by mercury-sensitive dissimilatory metal-reducing bacteria. Environ Sci Technol 40(21):6690-6696
Wirth MC, Berry C, Walton WE, Federici BA (2014) Mtx toxins from Lysinibacillus sphaericus enhance mosquitocidal cry-toxin activity and suppress cry-resistance in Culex quinquefasciatus. J Invertebr Pathol 115:62-67

Yilmaz M, Soran H, Beyatli Y (2006) Antimicrobial activities of some Bacillus spp. strains isolated from the soil. Microbiol Res 161(2):127-131

Yujun G, Rongying Z, Xiujuan Y, Shanshan G, Xiangqian L (2015) Highly efficient in vitro biosynthesis of silver nanoparticles using Lysinibacillus sphaericus MR-1 and their characterization. Sci Technol Adv Mater 16:015004. doi:10.1088/1468-6996/16/ $1 / 015004$

Yulianti T, Chasanah E, Tambunan USF (2012) Screening and characterization of L-glutaminase produced by bacteria isolated from Sangihe Talaud Sea. Squalen 7(3):115-121

Zamudio-Maya M, Narvaez-Zapata J, Rojas-Herrera R (2008) Isolation and identification of lactic acid bacteria from sediments of a coastal marsh using a differential selective medium. Lett Appl Microbiol 46(3):402-407 